Historic, Archive Document

Do not assume content reflects current scientific knowledge, policies, or practices. 



\section{APR 291916}

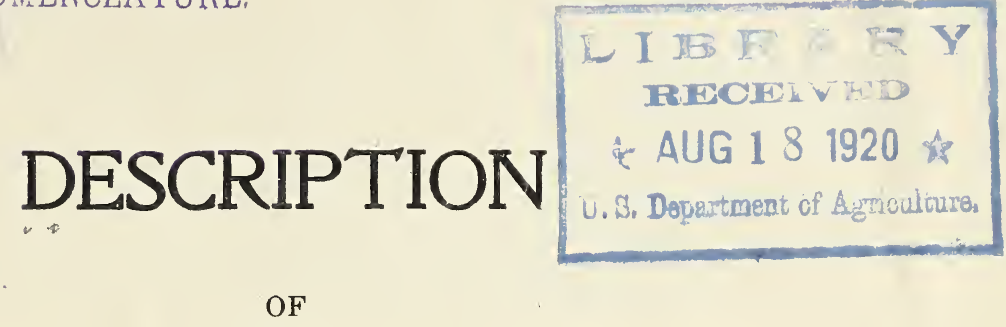

DIFFERENT VARIETIES

OF

Apples

GROWN BY

ALBERT WITHROW, Nurseryman.

\section{Ellijay. $\mathrm{Ga}$.}

1915.

\section{$\$$}




\section{APPLES.}

\section{EARLY VARIETIESS.}

EARLY MAY-Mediumsize, whitish-yellow, good bearer, very early, and sub-acid, good for cooking.

STRIPED JUNE-Ripens with red June, about same size, and flavor. good for cooking and good bearer.

CARolina June-(Red June) small or medium, deep red, good, productive, hardy, a free grower, very popular.

EARLY HARvest-Medium to large, pale yellow, fine flavor. Tree a moderate erect grower, and a good bearer, a beautiful and excellent variety for both orchard and garden.

Yellow Transparent-A Russian variety, imported in 1870 through the Agriculture Department. Ripen from ten days to two weeks earlier than Early Harvest.

\section{SUMMER VARIETIES.}

HoRsE-Fine bearer, acid flavor, superior for cooking, drying and shipping. One of the best summer apples.

- WhITE SUGAR-A large white sweet apple, excellent bearer.

RED ASTRACHAN-Large, roundish, nearly covered with deep crimson, overspread with a thick bloom; juicy, rich, acid, beautiful. The tree ls a vigorous grower with a largefoliage and a good bearer.

\section{EARLY FALL VARIETIES.}

JACK BURCH-(Fall Queen). A large red or streaked apple, ripening in September. Superior flavor and very hardy.

Fall PIPPIN-Very large, yellow, tender, juicy and rich. Tree vigorous. September.

I UChess OF Oldenburg-Of Russian origin. Large size, roundish; streaked with red an $\{$ yıllow. Rip ns in September.

\section{LATE FALL VARIETIES}

ARKansas BlaCK - Originated in northwest Arkansas, and is an enlarged and improved Wine Sap. Fruit almost black, flesh firm, rich, crisp, with a rich, hig 1 flar rr. Ostojer to Januacy.

Mammoth Black T'Wig-A very handsome and fine flavored apple, related to the Arkansas Black, but larger. flesh yellow and excellent flavor.

KINNARD'S CHOICE-One of the very best fall apples, fine keeper, dark red, good size, yellow flesh and flavor unexcelled.

Rомe BEAUTy-(Gillett's Seedling). Large roundish, yellow and light red; handsome, juicy, crisp, sub-acid; tree a moderate grower; good bearar. October. 
Wine SAP-Medium, dark red, sub-acid, excellent. Tree a moderate grower and abundant bearer. A favorite market variety. October.

BEN DAVIS-A large, handsome striped apple of good quality Tree very hardy, vigorous and productive. October to January.

RED LIMBERTWIG-One of the most popular and best late winter apples for this climate. Very hardy, early and abundant bearer, and keeps all winter.

IMPROVED SHOCKLY - Vigorous grower, and abundant bearer, good size and unexcelled as a keeper.

YATES-A very hardy and prolific apple, small, bearing in clusters like the crab, originated in Middle Georgia, and keeps all winter.

\section{SPECIAL VARIETIES.}

WALKING STICK-Of Indian origin, large size, greenish yellow, streaked with red, mild sub-acid, flavor unexcelled for eating, cooking or drying no other apple compares with it Tree extremely large. vigorous and spreading Ripens in July. Propagated and sold only by us.

- Gilmer-(Parks' Pippin). Originated in Gilmer County, Ga. New variety, large, yellow, abundant bearer, keeps ail winter, very valuable. Propagated only by this nursery.

Hopper PIPPIN-Originated in Gordon County, Ga., among the Cherokee Indians. Original tree still standing. Abundant bearer, large, yellow green, very fine flavor, and long keeper. P.opagatod only by this nursery.

DETROIT RED-One of the best and finest of the black apples. Tree compact bunchy top, Apple nice, smooth and very inne.

\section{TO WHOM IT MAY CONCERN:}

This is to certify that we, the undersigned citizens of Ellijay and Gilmer County, personally know J. A. Withrow, Nurseryman, and take pleasure in testifying to the fact he is a successful grower of reliable Nursery Stock. Hls trees are grown in this section and are acclimatized and are healthy and true to name.

\section{Signed.}

H. M, Ellington, Editor, Ellijay Courier. J. R. Waters, Liveryman. W. S. Dobbs, Minister. J. O. Crawford, Lumber Dealer. J. M. Garrett, Merchant. J. L. Weaver, Clerk superior Court. R. L. Milton, Sheriff. J. O. Hipp, Merchant. J. H. Clonts, Orchardist. R. L. Crawford, Orchardist. R. W. Burgess, Orchardlst, J. S. Tankersley, M. D. J. W. Davis, Merchant. W. S. Henson, County Treasurer. W. A. Cox, Ordinary. 
